\title{
Integrated Safety, Health And Environmental Management in The Construction Industry: Key Organisational Capability Attributes
}

DOI:

10.1108/JEDT-08-2021-0436

\section{Document Version}

Accepted author manuscript

Link to publication record in Manchester Research Explorer

Citation for published version (APA):

Asah-Kissiedu, M., Manu, P., Booth, C., Mahamadu, A. M., \& Agyekum, K. (2021). Integrated Safety, Health And Environmental Management in The Construction Industry: Key Organisational Capability Attributes. Journal of Engineering, Design and Technology. https://doi.org/10.1108/JEDT-08-2021-0436

Published in:

Journal of Engineering, Design and Technology

\section{Citing this paper}

Please note that where the full-text provided on Manchester Research Explorer is the Author Accepted Manuscript or Proof version this may differ from the final Published version. If citing, it is advised that you check and use the publisher's definitive version.

\section{General rights}

Copyright and moral rights for the publications made accessible in the Research Explorer are retained by the authors and/or other copyright owners and it is a condition of accessing publications that users recognise and abide by the legal requirements associated with these rights.

\section{Takedown policy}

If you believe that this document breaches copyright please refer to the University of Manchester's Takedown Procedures [http://man.ac.uk/04Y6Bo] or contact uml.scholarlycommunications@manchester.ac.uk providing relevant details, so we can investigate your claim.

\section{OPEN ACCESS}




\section{Journal of Engineering, Design and Technology \\ DOI: 10.1108/JEDT-08-2021-0436}

\section{Integrated Safety, Health And Environmental Management in The Construction Industry: Key Organisational Capability Attributes}

Millicent Asah-Kissiedu ${ }^{1}$, Patrick Manu ${ }^{2 *}$, Colin Booth ${ }^{3}$, Abdul-Majeed Mahamadu ${ }^{3}$, and Kofi Agyekum ${ }^{4}$

1 Department of Environmental Management and Technology, Koforidua Technical University, Koforidua, Ghana.

2 Department of Mechanical, Aerospace and Civil Engineering, The University of Manchester, Manchester, United Kingdom.

${ }^{3}$ Department of Architecture and the Built Environment, University of the West of England, Bristol, United Kingdom.

${ }^{4}$ Department of Construction Technology and Management, Kwame Nkrumah University of Science and Technology, Kumasi, Ghana

* Corresponding author

Email: Patrick.Manu@manchester.ac.uk

Telephone: 00441613067572

\section{Acknowledgments}

Appreciation is extended to the Commonwealth Scholarship Commission for funding this research (grant number: GHCS-2016-147). 


\begin{abstract}
Purpose: For construction organisations to be effective at implementing an integrated safety, health and environmental (SHE) management system, they require the right level of organisational capability. This capability includes the policies, systems and resources of the organisation. However, within the academic literature, it is unclear which organisational attributes of construction companies are important for implementing integrated SHE management. This study aims at exploring the organisational attributes that determine integrated SHE management capability as well as their relative priorities.
\end{abstract}

Design/methodology/approach: The study employed a literature review supported by expert verification and a subsequent three-round expert Delphi technique accompanied by applying the voting analytical hierarchy process (VAHP).

Findings: The study identified 20 attributes grouped under five main thematic categories. These are (i) strategy (the organisation's vision and top management commitment); (ii) process (the organisation's procedures and processes for SHE management); (iii) people (organisation's human resources, their competence, roles, responsibilities, and involvement in SHE management); (iv) resources (organisation's physical and financial resources for SHE management) and (v) information (SHE related documents, data, records, and their communication across an organisation). While these thematic categories and the attributes within carry different weights of importance, the strategy related attributes are the most important, followed by the people related attributes.

Originality/value: The results of this study should enable construction companies and key industry stakeholders to understand construction companies' capability to successfully implement an integrated SHE management system. Furthermore, construction companies should be able to prioritise efforts or investments to enhance their SHE management capability.

Keywords: construction industry; Delphi method; health and safety; environmental management; organisational capability; voting analytical hierarchy process

\title{
Introduction
}


The construction industry currently accounts for more than $10 \%$ of global gross domestic product (GDP) and enables national economic growth (Bawane, 2017; Suárez Sánchez et al., 2017). Despite its economic and social significance, the construction sector is one of the most dangerous industrial sectors accounting for several kinds of occupational fatalities and adverse environmental impacts ( HSE, 2018; Agyekum et al., 2021). At least 60,000 fatal accidents occur yearly on construction sites worldwide, representing one fatal accident every 10 minutes (Mubita et al., 2021). Furthermore, construction operations and activities generate water, noise and air pollution and account for about $20-35 \%$ of negative impacts on the environment, such as abiotic depletion and global warming ( Opoku, 2019). The International Labour Organisation (ILO) estimates that about $4 \%$ of the annual GDP is lost due to work-related accidents and their attendant injuries and illnesses (Tompa et al., 2021). There are reports of high economic costs in many countries resulting from these adverse environmental impacts and work-related tragedies. According to the Global Construction Perspectives and Oxford Economics (2015), the volume of construction output is estimated to grow by more than $85 \%$ worldwide by 2030. Notwithstanding the fact that the recent Covid-19 pandemic has the potential to affect this growth (ILO, 2021) (), the impact of construction operations on the environment and safety and health of workers could still worsen if appropriate actions are not taken.

Though the implementation of managements systems like the EMS and SHMS are useful in addressing SHE challenges within the construction industry, implementing and managing them separately in a company is onerous, costly and bureaucratic (Asah-Kissiedu et al., 2020). Ghana's construction industry is not different as construction companies have become incurious to implementing these standalone systems because of the associated cost, people's reluctance to change traditional practices, lack of expertise and staff, and the general institutional ineptness (Adjarko et al., 2016). These factors, most prominently the associated cost, have been corroborated by several researchers in other developing countries as the reasons why construction firms in these countries are reluctant to implement independent MSs (Owolana and Booth, 2016).

As construction safety issues are closely connected to environmental problems, initiatives aimed at improving safety during construction could lead to enhanced environmental management and vice versa (Zutshi and Creed, 2015). Therefore, some researchers and industry stakeholders have advocated for the integration of EMS and SHMS into a single 
integrated management framework that integrates SHE requirements into the work planning and implementation processes to effectively manage SHE issues in a sustainable, systematic and cost-effective way (Sui et al., 2018). This could be beneficial in reducing the number of fatalities, injuries, illnesses and the negative impacts of construction operations on the environment, leading to better SHE performance outcomes.

This initiative will not be bad, especially for a typical construction industry in a developing nation like Ghana, which accounts for the highest number of occupational accidents and deaths and work-related illnesses compared with other industrial sectors (Stemn, 2019; Boadu et al., 2020). The construction industry in Ghana is also tagged to be responsible for constant environmental degradation, pollution, substantial raw materials and energy consumption which continue to take their toll on the country's development (Agyekum et al., 2021). The high-risk nature of the construction industry, the weak institutional structure for implementing SHE standards and laxity in the enforcement of safety and environmental legislations on construction sites and the low commitment to SHE has seriously impeded the implementation of SHE standards and other initiatives on Ghanaian construction sites (Kheni and Braimah, 2014). This has, therefore, created the need to implement voluntary, proactive and systematic methods that will prevent accidents and negative environmental impacts on construction sites and assist construction companies in Ghana to improve SHE performance outcomes in the industry effectively.

Notwithstanding this need, the uptake of a prominent approach like the implementation of SHE management systems in the Ghanaian construction industry has been low (Adjarko et al., 2016) mainly due to cost and the bureaucracy that comes with the separate implementation of standalone management systems. There is a need for an integrated SHE management framework to effectively manage SHE risks and issues in the Ghanaian construction industry. Till now, there remains no single integrated SHE management framework for construction organisations to use, especially those within developing country settings like Ghana.

Such an integrated SHE management framework will mean that construction companies in Ghana must have adequate organisational capability, which encompasses policies, systems and resources to implement the framework effectively. In a comparative review of related literature, AsahKissiedu et al. (2020) identified key organisational attributes that could determine integrated SHE management systems and models in the construction industry to include senior management commitment to SHE, SHE risks management, SHE objectives and programmes, staff competencies, 
resources for SHE implementation, SHE roles and responsibilities, SHE communication, among others. As identified by Asah-Kissiedu et al. (2020), these attributes can enable construction companies and other potential stakeholders to appreciate construction companies' capability to implement an integrated SHE management system. Unfortunately, there is the tendency for the companies to have varying capabilities in respect of integrated SHE management system implementation. A significant gap in the literature that has been identified is the lack of empirical insight into what constitutes integrated SHE management capability in the Ghanaian construction industry., This gap is an indication of a lack of clarity regarding the determinants of integrated SHE management capability of construction companies in Ghana. Construction companies in Ghana must understand their current capability in respect of SHE management to guide continuous improvement efforts. Following the identification of this gap, this study was carried out to explore: 1) the attributes that determine the capability of a Ghanaian construction organisation to implement an integrated SHE management system; and 2) the relative priority of those capability attributes. With the identified capability attributes and their priority weights, construction companies will be able to assess their integrated SHE management capability and ascertain areas of strength and deficiencies. The paper begins with a review of relevant literature, which presents an outlook of SHE performance in the construction industry, the need for SHE improvement in construction and the research gaps relating to integrated SHE management capability. Subsequently, the research methods and findings are presented, followed by discussions and concluding remarks.

\section{Literature review}

The construction sector in many countries accounts for high rates of accidents, fatalities, injuries and illnesses. There are reports of high economic costs resulting from adverse environmental impacts and work-related tragedies. For instance, in the USA, the construction sector accounted for over 800 worker-related deaths in 2019(Bureau of Labour Statistics, 2020). Also, in the UK, the construction sector accounted for the highest number of fatal injuries to workers (i.e. 40 out of 111 worker fatalities) in 2019/20 (HSE, 2020). Across 28 European countries, the fatality rate of construction operations and activities was first among all economic activities in 2014 (Eurostat, 2017). While occupational accidents, injuries and 
illnesses are commonplace in construction globally (De Silva et al., 2018), their rates in developing countries are considered higher than in the developed countries (Williams et al., 2020). For instance, while in the UK 40 worker fatalities were recorded in 2019/207 (HSE, 2020), in Malaysia, the construction sector accounted for 66 out of 213 worker fatalities in 2020, which is the second highest among other industrial sectors (Department of Occupational Health and Safety, 2020).

Aside from being responsible for high rates of injuries, illness and fatalities, the sector also accounts for substantial consumption of natural and processed resources and energy (Agyekum et al., 2021). Estimates indicate that the construction sector consumes $50 \%$ of all raw materials consumed, $16 \%$ of water and $40 \%$ of the total energy consumed worldwide. Furthermore, it is responsible for $20-30 \%$ of greenhouse emissions and generates $17 \%$ of all wastes (Agyekum et al., 2021; ), making it one of the least sustainable industries globally. These occupational injuries, illnesses, fatalities, and negative environmental impacts have significant socioeconomic cost implications (ILO, 2012). For instance, in the UK, the cost of work-related injuries and diseases from all industries for 2017/18 is estimated to be around GBP 15 billion (HSE, 2018). In Singapore, the cost of occupational injuries and illnesses is SGD 10.45 billion, which is about $3.2 \%$ of the country's GDP (ILO, 2015). There is, therefore, a clear case for improving the SHE performance of the construction industry (Okoye and Okolie, 2014).

Several efforts have been made to address SHE problems in construction. Such efforts include introducing health and safety, environmental management regulations, and implementing management systems, particularly the EMSs and SHMSs based on management system standards (MSSs). Different international bodies have introduced these MSSs, with the most reputable being the Occupational Health and Safety assessment series (OHSAS 18001:2007), the International Organisation of Standardisation (ISO) Environmental Management System standard (ISO14001:2015) and the International Labour Organisation guidelines (ILO-OHS 2001). Over the years, the OHSAS 18001:2007 has emerged as the most widely used standard for SHMSs and ISO 14001 for EMSs, albeit a new international certifiable standard, ISO 45001, has recently been published to replace OHSAS 18001.

In the construction industry, EMSs and SHMSs are comprehensive and systematic tools that can assist construction companies in managing and controlling safety and health risks and challenges and improving environmental performance (Vasilca et al., 2021). They play a key role in addressing SHE problems, improving safety and working conditions and minimising 
occupational risks (Podgorski 2015; Olivera et al., 2016). However, EMSs and SHMSs implementation in construction companies are low (Tepaskoualos and Chountalas, 2017).

A good number of studies have been carried out in the last few decades regarding SHE management systems in the construction industry (Christini et al., 2004; Selih, 2007; Zeng et al., 2008; Griffith and Bhutto, 2008; Gasparik, 2009; Gangolells et al., 2011; Zutshi and Creed, 2015; Podgorski, 2015; Campos et al., 2016; Mohammadfam et al., 2017; Jazayeri and Dadi, 2017; Yiu et al., 2018). Although there has been a growing body of research on management systems in construction, particularly EMSs and SHMSs, these past researches have been mainly restricted to specific topics such as (1) awareness, motivators, costs, benefits and barriers of management systems ( Owolana and Booth, 2016; Schmidt and Osebold, 2017); (2) effectiveness of SHE management systems in addressing occupational accidents, SHE performance, pollution and waste reduction ( Yiu et al., 2018); (3) identification of key performance indicators for measurement and monitoring SHE MS performance (Podgorski, 2015; Haas and Yorio, 2016; Mohammadfam et al., 2017); and (4) integration of environment, quality, safety and health management systems ( Rebelo et al., 2015). Beyond these, some studies have concentrated on the elements of both stand-alone and integrated management systems (Rebelo et al., 2015; Yiu et al., 2018). Criticisms of individual/standalone systems have triggered studies regarding integrated management systems for being bureaucratic, costly, paper-driven and arduous ( Rebelo et al., 2015). However, within the existing construction SHE management literature, while arguments have been made for the integration of management systems ( Rebelo et al., 2015), empirical insight regarding what constitutes integrated SHE management capability is scarce. These insights are important, especially for organisations seeking to combine safety and health management and environmental management as a single integrated management function. In other words, it is unclear what organisational attributes are required to implement an integrated SHE management system by a construction company. As a result, a thorough indication of what constitutes integrated SHE management capability should be identified. This paper focuses on providing empirical realities regarding integrated SHE management capability in construction.

\section{Research method}

To identify organisational attributes relevant to integrated SHE management in construction, three research methods were employed. These comprise: (1) a systematic literature review to identify potential integrated SHE management capability attributes and a preliminary expert 
verification process to ascertain the appropriateness and comprehensiveness of the identified attributes; (2) application of a Delphi technique to generate consensus regarding the importance of the attributes; and (3) application of a voting analytical hierarchy process (VAHP) to generate weights of importance based on the outcomes of the Delphi technique.

The Delphi technique has proven to be a popular and reliable technique for decision making (Adler and Ziglio, 1996; Hallowell and Gambatese, 2010). Over the years, its applications in construction engineering management (CEM) research as a methodology for eliciting knowledge, prioritising elements and decision making, where there is limited knowledge about the research area, has increased greatly (Ameyaw et al., 2016; Ogbeifun et al., 2017; Poghosyan et al., 2020; Evans et al., 2021). In this study, while the comprehensive literature review supported by expert verification enabled elicitation of integrated SHE management capability attributes, the Delphi technique combined with VAHP (a -multi-criteria decision making method) enabled the prioritisation of the attributes. The research process is shown in Figure 1.

\section{[Insert Figure 1]}

\section{Review of literature supported with expert verification of attributes}

Identification of Integrated SHE management capability attributes (literature review)

A systematic review of literature related to SHE management, and not limited to construction, was used to generate a list of potential integrated SHE management capability attributes. Literature sources comprised international standards (e.g., ISO 45001, OHSAS,18001, ISO14001), published guides on SHE management and academic publications, including journal articles, books and conference papers (Charef et al., 2018). Furthermore, relevant literature related to capability maturity models on safety, health and environmental management (e.g. Fleming, 2001; Sharp et al., 2002; Strut et al., 2006; Filho et al., 2010) was also reviewed.

Searches were carried out within the academic databases: Elsevier's Scopus, Thomson Reuter's 'Web of Science', ASCE (American Society of Civil Engineers), Emerald and Google Scholar. The search terms used are: 'environmental management in construction'; 'construction health and safety'; ' 'occupational safety and health management'; 'environmental management'; 
'environmental management maturity'; 'ISO 14001'; 'construction health and safety management system'; 'OSHAS 18001'; 'EMS'; 'environmental, health and safety management'; 'OHMS',' IMS'; 'environmental management maturity model'; and 'health and safety maturity model'. In all, a total list of 1210 publications was generated with the above search terms. This list of literature materials was then systematically scaled down to 20 most relevant literature using the four-phase PRISMA approach developed by Moher et al. (2009), as shown in Figure 2 below. The full-text content criteria used in assessing specific metadata are given below:

- Best practices or requirements for SHE management in construction

- Environmental, health and safety practises in construction

- Studies on the implementation of safety, health and environmental management systems

From the review, it was realised that existing SHE management guides and international standards generally follow Deming's Plan-Do-Check-Act (PDCA) management approach and, ttherefore, share common requirements that allow most of their elements to be integrated. As a result, in developing the list of organisational attributes that determine integrated SHE management capability, information from the 20 publications, consisting of established internationally recognised SHE management standards and published works, were extracted by comparing their components to determine key similarities and differences; thereby, establishing potential integrated SHE management capability attributes. In the end, 27 potential attributes were obtained. The main literature sources are presented in Appendix A.1, and the 27 attributes are also shown in Table 1.

[Insert Figure 2]

[Insert Table 1]

\section{Expert verification}

A questionnaire containing the 27 attributes was developed and sent to 12 experts with expertise in SHE management in construction. The purpose was to draw on the experts' SHE management expertise to ascertain the appropriateness and comprehensiveness of the $27 \mathrm{SHE}$ management capability attributes generated from the literature review. The experts were selected following Hallowell and Gambatese (2010) guidance in selecting experts for expert 
group techniques (e.g., a minimum of five years' experience in safety, health and environmental management practice and research in construction). Collectively, the experts had knowledge and expertise in SHE management in the construction industry. The demographic information of these experts is presented in Appendix A.2. The questionnaire requested the experts to review and indicate the relevance of the attributes to the development of an integrated SHE management system in construction. They were also asked to identify other suitable capability attributes that may have been missed. Results of the expert's verification are presented in Tables 4 and 5 of the results sections.

\section{Delphi process}

The Delphi technique (DT) is an iterative process used to collect and collate opinions of a group of experts on specific issues, using a series of questionnaires interspersed with controlled feedback to obtain the most reliable consensus (Adler and Ziglio, 1996; Linstone and Turoff, 2011). It has proven to be a popular and reliable technique for decision making and is best suited in fields with no or incomplete knowledge about a problem or phenomena (Adler and Ziglio, 1996; Skulmoski et al., 2007). This technique has four main features: (1) anonymity of participants; (2) iteration; (3) controlled feedback; and (4) statistical aggregation of participant responses (Adler and Ziglio, 1996; Rowe and Wright, 1999). DT typically includes at least two rounds (i.e., iterations) of experts answering questions anonymously and providing opportunity between rounds for them to reconsider changes to their responses (Rowe and Wright, 1999). The process continues until consensus (i.e., certain level of agreement) has been achieved (Skulmoski et al., 2007). In this study, the DT was used to generate consensus on the importance of the relevant integrated SHE management capability attributes through collective intelligence of construction professionals with knowledge and expertise in SHE management. The experts were recruited from the Ghanaian construction sector. Table 2 shows the main features of the Delphi technique as applied in this research. Purposive sampling was used to recruit participants for the study, which was supplemented by snowball sampling, whereby experts, who were invited by the researchers, subsequently invited other experts within their professional groups. Invitation letters were e-mailed to 70 potential expert panellists to explore their availability to participate. Experts were identified from construction professional groups and associations. 
From the 70 invitations, 57 experts registered interest in participating in the Delphi process. However, only 41-30 experts participated in the Delphi rounds. Most Delphi studies in construction engineering management make use of between 7 to 35 participants. For instance, in the study of Hallowell and Gambatese (2010), eight participants were used. Skulmoski et al. (2007) made use of a minimum of ten participants in their study. Ameyaw et al. (2016) recommended that in CEM Delphi applications, participants can range from 3-90. However, most similar studies have settled on 15 to 35 participants (Ameyaw et al., 2016). With this background, the number of experts (i.e., 12) who participated in this study was considered acceptable. Three rounds of Delphi interspersed with controlled feedback were undertaken. The demographic information of Delphi experts is presented in Appendix A.3.

The 20 integrated SHE management capability attributes and the five thematic categories were incorporated in a questionnaire. In the first round, experts were asked to rank the five thematic categories based on their level of importance to the implementation of SHE management in construction. Similarly, the participants were asked to rank attributes within each of the categories. Forty-one experts completed the first round. In the second round, the median ranks for the five categories and the attributes within each category in the first round were incorporated and customised for each expert by including the expert's first-round responses. The questionnaire was sent via an email attachment, and experts were asked to reflect on the information (i.e., their responses and the median ranks) and then rank the attributes again. The ability for each member of the expert panel to re-evaluate, review, and further change their thoughts on the research matter is one of the important features of the Delphi technique (Skulmoski et al., 2007).

Thirty-one experts completed the second-round questionnaire. At the end of the second round, an agreement analysis using Kendall's coefficient of Concordance $(W)$ was used to ascertain the degree of agreement among the expert panel members in their rankings of the capability attributes. The Kendall coefficient of concordance (W) (Legendre, 2005) is defined as

Equation (1)

$$
W=\frac{12 \sum R_{i}^{2}-3 p^{2} N(N+1)^{2}}{p^{2} N\left(N^{2}-1\right)-p \sum T_{j}}
$$


where, $\sum R_{i}^{2}$ is sum of the squared sums of ranks for each of the $N$ objects being ranked; $p$ is the number of respondents; and $T_{j}$ is the correction factor required for the $j$ th set of ranks for tied observations given by $T_{j}=\sum_{i=1}^{g_{j}}\left(t_{i}^{3}-t_{i}\right)$, where $t_{i}$ is the number of tied ranks in the $i$ th grouping of the ties, and $g_{j}$ is the number of groups of ties in the $j$ th set of ranks (Zar, 1999; Legendre, 2005). Perfect agreement is indicated by a value of 1 , while complete disagreement is indicated by a value of 0 . As the coefficient $(W)$ moves closer to 1 , there is consistency in the responses and a strong agreement (Field, 2013). Schmidt (1997) states that a coefficient $(W)$ value $\leq 0.1$ is unacceptable; however, a value of 0.1 up to 0.3 is low, 0.3 to 0.5 is moderate, while a value of 0.5 up to 0.7 is high and good, and 0.7 up to 0.9 or above is very high and excellent. In this study, a coefficient $(W)$ value $\geq 0.4$ was considered a suitable level of agreement. The IBM SPSS statistics version 24 was used to determine Kendall's $W$ and the level of significance.

\section{Voting analytical hierarchy process (VAHP)}

Analytic hierarchy process (AHP) is a multi-criteria methodology, which permits the relative assessment and prioritisation of alternatives (Saaty, 1980). AHP enables complex and unstructured problems to be broken down into alternatives arranged into hierarchical order. The method then quantifies the relative weights or priorities of a given set of alternatives based on the subjective judgement of the decision maker/experts through pairwise comparison of the criteria. The paired comparison is undertaken using a scale, which indicates the strength to which one alternative or criterion dominates another alternative or criterion. Using the scaling process, numerical priorities or weights are calculated for each criterion or alternatives. Since its emergence in the 1980s, AHP has been found to be a valuable multi-criteria decision method, resulting in its application in several research domains, including CEM (Ameyaw et al., 2016). In several CEM studies, AHP has been used in conjunction with DT (Ameyaw et al., 2016). For instance, Vidal et al. (2011) combined DT with AHP to generate a list of prioritised best practices necessary for successfully managing projects requiring a higher level of fast tracking. Despite its usefulness, AHP has some limitations. A key limitation is the difficulty in applying paired comparison, particularly with several criteria/alternatives (HadiVencheh and Niazi-Mortlagh, 2011). As a result, Liu and Hai (2005) developed the voting analytic hierarchy process (VAHP), an easier weighting procedure than the AHP's paired comparison. VAHP uses a voting ranking approach instead of a paired comparison method to 
determine the weights of a set of criteria and sub-criteria in a hierarchical structure (Lui and Hai, 2005). Given the large numbers of integrated SHE, management capability attributes in this study, the VAHP approach was used. Manu et al. (2019) similarly used DT followed by the application of VAHP to determine the weight and rank of attributes that determine design for health and safety capability of design firms in the construction industry.

\section{Implementation of VAHP}

In this study, the use of VAHP involved a six-step process adapted from Liu and Hai (2005).

Step 1-Selection of criteria: in the case of this study, the five thematic categories of integrated SHE management capability attributes constituted the criteria.

Step 2- Structure the hierarchy of the criteria: 20 integrated SHE management attributes constituted the sub-criteria within the five thematic categories as shown in Figure 3.

Step 3-Prioritise the criteria: From the second round of Delphi, 31 experts ranked the five categories of attributes. The ranking by the experts is shown in Table 3.

\section{[Insert Figure 3]}

Step 4-Prioritise the sub-criteria: From the second round Delphi, 31 experts ranked the attributes within the "strategy", "process", "people", "resources" and "information" categories. From the third round of Delphi, 30 experts ranked attributes within the "resources" category. Table 6 shows the ranking by the experts.

Step 5-Calculate the weights of the criteria and sub-criteria: The equations proposed by HadiVendch and Niazi-Mortlagh (2011) for calculating weights were applied based on the five thematic categories of attributes and the number of attributes within each category. The equation is expressed as:

Equation (2)

$$
W_{1} \geq 2 W_{2} \geq \cdots \geq \mathrm{SW}_{S} \geq 0
$$


Where $w$ is a coefficient weight applied to the vote ranking of each criterion to determine the criterion weight, and $s$ is the number of positions; therefore, $w_{\mathrm{s}}$ is the coefficient weight for the $s$ th position. For example, for four criteria being ranked, $w_{1}$ is the coefficient weight for the first position, $w_{2}$ is the coefficient weight for the second position, $w_{3}$ is the coefficient weight for the third position, and $w_{4}$ is the coefficient weight for the fourth position. Based on equations (2) and (3), the coefficient $w_{\mathrm{s}}$ for the relevant number of capability attributes and sub-attributes were derived and presented in Table 3.

\section{[Insert Table 3]}

Based on the Delphi rankings, the VAHP was used to determine weights of the five thematic categories and attributes within each category (i.e., sub-attributes), by multiplying the coefficient weights presented in Table 3 by the ranking data from the Delphi rounds. Afterwards, the obtained weights for the categories were normalised so that they add up to one. Similarly, the obtained weights for attributes in each category were normalised, as shown in Table 9. For example, in the third round of Delphi, which involved 30 experts, for the resource category, physical resource was ranked first by 26 experts and second by four experts. Financial resource was ranked first by 21 experts and second by nine experts (Table 8). According to Lui and Hai (2005), the weights of these attributes are determined as follows:

- $\quad$ Physical resources $=(26 * 0.6667)+(4 * 0.3333)=18.667$

- Financial resources $=(21 * 0.6667)+(9 * 0.3333)=17.00$

\section{Step 6- calculate global weights and rank criteria by using the VAHP formula:}

The final stage of the weight calculation in the VAHP procedure is to obtain the global (i.e., overall) weights of sub-attributes. This is achieved by multiplying the normalised weight of a thematic category (i.e., main attribute) by the normalised weight of the sub-attributes within that category. For example, the normalised weight of "Information" was multiplied by the normalised weights of its sub-attributes: "Communication", "Documentation and control"' and "Knowledge management".

Normalised weight for the thematic category "Information" $=0.1171$

- Communication $=0.45974 * 0.1171=0.0539$

- Documentation and Control $=0.29610 * 0.1171=0.0347$

- $\quad$ Lessons and Knowledge management $=0.24416 * 0.1171=0.0286$ 
Similarly, this step is applied to all the other capability attributes. The overall outcomes of the VAHP are presented in the results section.

\section{Results and discussion}

This section is structured into three main headings: results and discussion of expert's verification; results and discussion of Delphi; and results and discussion of the VAHP.

\section{Results and discussions of expert verification}

A total of nine out of the twelve experts responded to the questionnaire. Overall, the expert verification revealed that for each of the attributes, over half of the experts (i.e., a simple majority) agreed that it is relevant to the development of an integrated SHE management system in construction (Table 4). Moreover, the experts did not suggest any new attributes. Finally, the 27 validated attributes were consolidated (based on their similarity) into 20 integrated SHE management capability attributes. These attributes were subsequently categorised, based on their relatedness, into the five thematic areas of integrated SHE management capability, namely: strategy; people; process; resources; and information. Detailed descriptions of each of them are presented in Table 5.

Categorisation of the capability attributes is consistent with the concept of organisational capability maturity, although specific to integrated SHE management (Paulk et al., 1993; Succar, 2009; Randeree et al., 2012). Additionally, the integrated SHE management capability attributes share similarities with some existing capability maturity models' key practices and process areas. The capability attributes definitions align with the six key safety factors of the health and safety maturity model (HSMM) by Goggin and Rankin (2010), namely: "management commitment", "safety, policy and standards", "worker involvement and commitment", "hazard identification, reporting, and control", "equipment materials and resources" and "working environment". Although there are some similarities of the SHE management capability attributes to that of Goggin and Rankin's (2010) six factors, the HSMM 
model inadequately covers incident investigations and management and preventive actions, which feature in the integrated SHE management capability attributes found in this study.

Furthermore, attributes definitions align with the elements of the UK Coal maturity model (Foster and Hault, 2013) and the safety management processes of Strutt et al. (2006) Design Safety Capability Maturity Model (DCMM). While some attributes align with Strut et al.'s (2006) model attributes, there is much focus on the activities required to deliver a safe design than on areas of organisational capability, such as experience, which is an important attribute identified in this study. Moreover, some of the integrated SHE management capability attributes align with common features of organisational capability; senior management commitment and leadership, financial, physical, and people/ human resources (Succar, 2009; Manu et al., 2019; Poghosyan et al. 2019), while others relate specifically to SHE management, e.g. hazards/risks identification and management, incidents investigations and SHE performance monitoring and measurement (Fleming et al., 2001; Filho et al., 2010). The integrated SHE management capability attributes, particularly the 'strategy' (senior management leadership, commitment, policy, responsibilities and accountability), is very vital to the success of SHE management from all levels and functions of a construction organisation (Ejdys et al., 2016; Manu et al., 2019).

\section{[Insert Table 4]}

[Insert Table 5]

\section{Results and discussion of the Delphi process}

The results of the three round Delphi study are summarised in Table 6. Across the three rounds, there were minimal changes in the median scores except for "information", "auditing", and "emergency preparedness", whose medians changed from 4 (in round one) to 5 (in round 2), as well as "management of outsourced SHE personnel" whose median changed from 3 (in round one) to 4 (in round 2), "competence" whose median changed from 2 ( in round one) to 1 (in round two), "SHE training" whose median changed from 2 (in round one) to 3 (in round two) and "Employee involvement in SHE” whose median also changed from 2 (in round one) to 3 (in round two). The significant Kendall's Coefficient of Concordance $(W)$ values obtained for ranking the thematic categories shows that there was consensus in the experts ranking between round one and round two. Similarly, there was consensus between round one and 
round two in the experts ranking of the strategy related attributes, process related attributes, people related attributes, and information related attributes. Moreover, there was consensus improvement between the two Delphi rounds, as shown by the increase in the Kendall's coefficient of concordance $W$ values. While there was improvement in the Kendall's $W$ for ranking the resources related attributes between Delphi round one and two, the Kendall's W was insignificant and, therefore, necessitated the third round of Delphi.

In the third round of Delphi, some of the experts' ranking of the "resources" attributes differed from round two. As a result, the median rank slightly changed. Although there was an increase in the Kendall's W at the end of the third round, consensus on the "resource" category was still not achieved. Following the suggestion by Dalkey et al. (1970) that states Delphi results are most accurate after two rounds but become less accurate as a result of additional rounds, the Delphi process in this study was terminated after the third round. Additionally, a check for saturation using the Wilcoxon signed rank test $(Z)$ showed no significant statistical difference between the second and the third rounds responses for the attributes within the "resources" category. This implied a further Delphi round was unlikely to yield consensus. As a result, all the 20 capability attributes were utilised in the VAHP to ascertain their relative priorities. Results of the Wilcoxon signed rank test are shown in Table 7. The vote ranking data of the second and third rounds of the Delphi are also presented (Table 8).

\section{[Insert Table 6]}

[Insert Table 7]

[Insert Table 8]

\section{Results and discussions of the VAHP}

The results of the VAHP are summarised in Tables 9 and 10. In relation to the thematic groupings of the attributes, "strategy" is the most important, followed by "people". Collectively, these two categories account for $53.90 \%$ of the weights of the five categories. "Information" is the least important, and "processes" is ranked $3^{\text {rd }}$ above "resources". The emergence of "strategy" as the most important, is perhaps unsurprising, due to the recognition of leadership, commitment, vision, direction, statement of objectives and targets, policy and management plans as relevant keystones of SHE management (Hale et al., 2010; Heras - 
Saizarbitoria, 2011; Ejdys et al., 2016; Zaira and Hadikusumo, 2017). Furthermore, the emergence of the "strategy" and "people" categories as the topmost categories align with the findings of Manu et al. (2019). Manu et al. (2019), in their study of design for occupational safety and health (DfOSH) organisational capability, found that "strategy" (i.e., the consideration of DfOSH in organisation's vision as well as the top management support for DfOSH) and "competence" (i.e., the competence of organisation's design staff in respect of DfOSH) were the most important categories of capability attributes.

A thorough check of the attributes within the thematic categories (i.e., Table 9) shows that for strategy related attributes, "Senior management commitment to SHE" and "SHE policy" together accounted for over $68.70 \%$ of the category weight. For process related attributes, "SHE risks management" is the most important attribute, followed by "SHE operational control" and "performance measurement". Collectively, these three accounts for $58.70 \%$ of the category weight. Regarding the people related attributes, "competency" is the most important, followed by "roles and responsibilities". Together, these two attributes account for $62.10 \%$ of the category weight. "Physical SHE resources", which accounts for $52.34 \%$ of the category weights, is the most important attribute of the two attributes in the resource category. "Communications" emerged as the most important attribute of the three "information" attributes.

Based on the global weights, senior management commitment to SHE emerged as the most important attribute, followed by SHE policy. This is followed by physical SHE resources, competency, financial resources, SHE objectives and targets, and SHE communications. Collectively, these seven attributes account for approximately $57.47 \%$ of the global weights. Inclusion of the next three attributes (i.e., SHE risks management, SHE management programs and plans and, Roles and responsibilities) increases to $72.50 \%$, therefore indicating 10 out of the 20 attributes (i.e. half) account for over $70 \%$ of the global weights. The least important attribute is "incidents investigations". Above it is "SHE auditing" and "Emergency preparedness and response", "management of outsourced personnel" and "performance measurements" in that order.

\section{[Insert Table 9]}


While all attributes within the strategy category are important for effective SHE implementation, "Senior management commitment to SHE" and "SHE policy" accounted for over $60 \%$ of the strategy category weights and $23 \%$ of the global weights of all the capability attributes. This emphasis is noteworthy, given earlier studies have indicated that senior management commitment in the form of providing a priority to SHE issues leads to its effective management and better performance (Aksorn and Hadikusumo, 2008; Boughaba et al., 2014; Ejdys et al., 2016; Zaira and Hadikusumo, 2017; Manu et al., 2019). For companies to achieve their objectives and targets, there is a need for full support and firm commitment from senior management and other members of the organisation. Strong, visible leadership and commitment plays a key role in developing a strong culture of safety within a company and also creates safer and healthier workplaces (Lai et al., 2011).

For effective SHE implementation, the commitment and provision of adequate and appropriate resources is paramount. As a result, it is not surprising that the attributes in the "resources" category were among the five topmost capability attributes based on the global weights. Within the "resources" category, the physical SHE resources attribute was the most important attribute, followed by financial resource. This finding reflects current trends of research and implementation in SHE management in construction, which emphasises the need for the usage of new construction materials, equipment and techniques, and the application of information technology tools for improved SHE management, all of which require financial commitment (OSHA, 2016; Suárez Sánchez et al., 2017).

With the "people" category, which emerged as the second most important capability category, the "SHE competence" attribute was found to be the most important within the cluster. The category also encapsulates SHE roles and responsibilities, training and employee consultation and involvement. In this study, competence is described as the skills, knowledge and experience of personnel to undertake responsibilities and perform SHE activities. It is not surprising that it emerged as the most important people related attribute. In existing studies, SHE skills, experience, knowledge, and attitude of employees drive other aspects of organisational performance and, therefore, are critical to the success of SHE management programmes (Lopez-Arquillos et al., 2015; Hallowell and Hansen, 2016; Manu et al., 2019). Whereas personal competency is desirable for SHE management in a construction company and is seen as a part of organisational capability, the study highlights the relative importance 
of training. This attribute emerged as the third most important attribute in the people related category and ranked 13 th based on the global weights. SHE training is crucial to the success of the SHE management system and is one means by which SHE management practices can be improved (HSE, 2013; Han et al., 2014; OSHA, 2016). In addition, “employee's consultation and involvement" is another important attribute that influences the effectiveness of the integrated SHE management system. According to the European Commission (2008), in addition to senior management support, employees' participation is vital to the success of SHE implementation. Management needs to get their employees to be more knowledgeable and informed about SHE issues since without their commitment and involvement, SHE implementation would be an arduous task. This emphasis on worker consultation and participation is consistent with the OSHA and ISO standards, enforcement policies and procedures on health, safety and environmental management, which recognise the rights and roles of employees and their representatives in matters of SHE management. It was ranked $12^{\text {th }}$ based on the global priority weights, indicating its importance to SHE management. Having the right personnel doing the right thing at the right time and promoting employee's engagement and involvement in SHE management helps to improve safety performance (Wachter and Yorio, 2014).

Hazard identification and risks assessment and control are also evident from the findings; therefore, the emergence of the "SHE risks management" as a relevant capability attribute for integrated SHE management and ranked third among the process related attributes. Altogether, the process related capability attributes have been similarly recognised as germane to effective implementation of safety management (Filho et al., 2010; HSE, 2013; OSHA, 2016). However, SHE audits, which are a key aspect in enforcing SHE measures and continual improvement (HSE, 2013; ISO, 2015), emerged as one of the least important attributes based on the global priority weights. Systematic identification and reporting of SHE management system deficiencies allow management to focus on the environment, safety and wellbeing of employees, improve SHE performance and ensure the integrated system's cost-effectiveness.

"Communications" emerged as the most important attribute of the information category attribute. This finding is consistent with previous studies, which indicates that regular communication of SHE issues and other relevant SHE information and feedback at all levels of the organisation is a major SHE management practice that positively influences the safety performance of an organisation (Fernandez-Muniz et al., 2012; Boughaba et al., 2014). There 
is, therefore, the need for accurate and clear information on SHE issues coming into the organisation, flowing within it, and going out from it.

\section{Conclusion}

Construction safety issues are closely connected to environmental problems. The initiatives aimed at improving safety during construction could lead to enhanced environmental management and vice versa. There has been a strong need for construction companies to manage SHE issues consistently and effectively. Some researchers and industry stakeholders have advocated for the integration of EMS and SHMS into a single integrated management framework that integrates SHE requirements into the work planning and implementation processes to effectively manage SHE issues in a sustainable, systematic and cost-effective way. Unfortunately, the uptake of a prominent approach like the implementation of SHE management systems in the construction industry of developing countries has been low due to several issues: the industry's inadequate organisational capability to implement such a framework effectively. Therefore, this study was initiated to explore the organisational attributes that determine integrated SHE management capability and their relative priorities.

Through a systematic review of related literature supported by expert verification and subsequently a three-round expert Delphi technique accompanied by the application of the voting analytical hierarchy process (VAHP), data were obtained for the study. The findings revealed that the integrated SHE management capability comprises 20 distinct capability attributes, which are categorised into five thematic areas, namely: strategy (the organisation's vision and senior management commitment for SHE management); process (organisation's procedures, processes and systems for SHE management); people (the organisations human capital, their roles, responsibilities and involvement in SHE management); information (the SHE related documents, data, lessons, records and their communication across an organisation); and resources (i.e. the financial and physical resources necessary for effective SHE management. The study further highlighted the varying level of importance of the attributes within the resource, people, process, and information categories. The prioritisation revealed that senior management commitment to SHE management, the presence of SHE policy statement, adequate resources, competent staff, and well-defined objectives and targets are vital to the success of integrated SHE management in construction. 
The implications of the findings manifest in three folds. Firstly, the findings contribute to the state-of-the-art issues of organisational attributes required for a typical construction company to implement an integrated health, safety and environmental management system in a developing country context. Secondly, the identified capability attributes reflect the key aspects of good health, safety and environmental management system, which emphasises a proactive and systematic approach to managing SHE issues in construction. The identified integrated SHE management capability attributes and their priority weights should enable relevant industry stakeholders to better understand the construction company's capability to implement an integrated SHE management system effectively. Additionally, with the identified capability attributes and their priority weights, construction companies should be able to assess their integrated SHE management capability, ascertain areas of strengths and deficiencies and subsequently prioritise efforts or investments targeted at addressing the areas of deficiencies to enhance their SHE management capability.

A limitation of this study is that the study was based on the professional views of SHE management experts and other practitioners within the Ghanaian construction industry. Therefore, findings may be peculiar to SHE management in the Ghanaian construction industry. As a recommendation for further study, the study could be replicated in other developing countries and in other industrial sectors other than construction for further comparison of the organisational attributes that determine integrated SHE management capability and their relative priorities. 


\section{References}

Adler, M., and Ziglio, E. (1996), Gazing into the Oracle: The Delphi Method and Its Application to Social Policy and Public Health. London: Jessica Kingsley.

Adjarko, H., Offei, I., and Frederick, J. (2016) Implementation of environmental management systems by Real Estate Developers in Ghana. International Refereed Journal of Engineering and Science (IRJES). 5(4), pp. 62-69

Agyekum, K., Botchway, S.Y., Adinyira, E. and Opoku, A. (2021), "Environmental performance indicators for assessing sustainability of projects in the Ghanaian construction industry", Smart and Sustainable Built Environment, ahead-of-print, doi: 10.1108/SASBE11-2020-0161, pp. 1-33.

Agyekum, K., Ghansah, F.A., Tetteh, P.A. and Amudjie, J. (2021), "The role of project managers (PMs) in construction health and safety implementation in Ghana", Journal of Engineering, Design and Technology, Vol. 19 No. 1, pp. 245-262.

Ameyaw, E.E., Hu, Y., Shan, M., Chan, A.P.C., and Le, Y. (2016), “Application of Delphi method in construction engineering and management research: A quantitative perspective", Journal of Civil Engineering and Management, Vol. 22 No. 8, pp. 991-1000.

Aksorn, T., and Hadikusumo, B.H.W. (2008), "Critical success factors influencing safety program performance in Thai construction projects”, Safety Science, Vol. 46 No. 4, pp.709 727.

Asah-Kissiedu, M., Manu, P., Booth, C. and Mahamadu, A.-M. (2020), "Organisational attributes that determine integrated safety, health and environmental management capability", MATEC Web of Conferences 312 02009, pp. 1-13.

Bawane, O. P. (2017), "Construction quality management: Issues and challenges before construction industry in developing countries". International Journal of Engineering Development and Research (IJEDR), Vol. 5 No. 3, pp. 1208-1211.

Boadu, E.F., Wang, C.C. and Sunindijo, R.Y. (2020), "characteristics of the construction industry in developing countries and its implications for health and safety: An exploratory study in Ghana", International Journal of Environmental Research and Public Health, Vol. 17 No. 11, pp. 4110.

Boughaba, A., Hassane, C., and Roukia, O. (2014), "Safety culture assessment in Petrochemical industry: A comparative study of two Algerian plants". Safety and Health at Work. Vol. 5 No. 2, pp. 60-65.

British Standards Institute (BSI) (2007), OHSAS 18001- Occupational Health and Safety Management Systems -Specification. London.

Bureau of Labor Statistic (2020) National census of fatal occupational injuries in 2019. Bureau of Labor Statistics. Available from: https://www.bls.gov/news.release/pdf/cfoi.pdf [Accessed 4 October 2021] 
Campos, L.M.S., Trierweiller, A.C., Nunes De Carvalho, D., and Šelih, J. (2016), "Environmental management systems in the construction industry: a review", Environmental Engineering and Management Journal, Vol. 16 No. 2, pp. 453-460.

Charef, R., Alaka, H., and Emmitt, S. (2018) Beyond the third dimension of BIM: A systematic review of literature and assessment of professional views. Journal of Building Engineering. 19(5), pp. 242-257.

Christini, G., Fetsko, M., and Hendrickson, C. (2004), "Environmental management systems and ISO 14001 certification for construction firms", Journal of Construction Engineering Management, Vol. 130 No. 3, pp. 330-336.

Dalkey, N., Brown, I., and Cochran, S. (1970), "Use of self-ratings to improve group estimates: Experimental evaluation of Delphi procedures". Technological Forecasting, Vol.1 No. 3, pp. 283-291.

Department of Occupational Health and Safety (DOSH) (2020) Occupational accident statistics by sector until december 2020 (reported to DOSH only). Department of Occupational Health and Safety [online]. Available from:

https://www.dosh.gov.my/index.php/statistic-v/occupational-accident-statistics/occupationalaccident-statistic-2020/3876-occupational-accidents-statistics-by-sector-january-todecember-2020-investigated/file [Accessed 4 October 2020].

De Silva, N., Rathnayake, U. and Kulasekera, K.M.U.B. (2018), "Under-reporting of construction accidents in Sri-Lanka", Journal of Engineering, Design and Technology, Vol. 16 No. 6, pp. 850-868.

Ejdys, J., Matuszak-Flejszman, A., Szymanski, M., Ustinovichius, L., Shevchenko, G., and Lulewicz-Sas, A. (2016), "Crucial factors for improving the ISO 14001 environmental management system", Journal of Business Economics and Management, Vol. 17 No. 1, pp. 52 73.

European Commission (2008) EMAS-Eco-Management and Audit Scheme Systematic Environmental Management Fact Sheet. ${ }^{\text {rd }}$ ed., available at:

https://www.emas.de/fileadmin/user_upload/04_ueberemas/PDFDateien/Unterschiede_iso_e $\underline{\text { n.pdf }}$ (assessed 17 August 2018)

Eurostat (2017) Health and Safety at Work. Eurostat Database. [online]. Available from: (http://ec.europa.eu/eurostat/web/health/health- safety-work/data/database. [Assesed 10 February 2019]

Evans, M., Farrell, P., Mashali, A. and Zewein, W. (2021), "Critical success factors for adopting building information modelling (BIM) and lean construction practices on construction mega-projects: a Delphi survey", Journal of Engineering, Design and Technology, Vol. 19 No. 2, pp. 537-556.

Fernández-Muñiz, B., Montes-Peón, J.M., and Vázquez-Ordás, C.J. (2012), "Safety climate in OHSAS 18001-certified organisations: Antecedents and consequences of safety behaviour"., Accident Analysis and Prevention, Vol. 45, pp. 745-758. 
Fleming, M. (2001), "Safety Culture Maturity Model. Report 2000/049". HSE. Colegate, Norwich, available at: www.hse.gov.uk/research/otopdf/2000/oto00049.pdf. PDF file (assessed 26 June 2018).

Field, A. (2013), Discovering Statistics using IBM SPSS Statistics. 4th ed. Sage.

Filho, A.P.G., Andrade, J.C.S., and Marinho, M.M. de O. (2010), "A safety culture maturity model for petrochemical companies in Brazil”, Safety Science, Vol. 48 No. 5, pp. 615-624.

Foster, P., and Hoult, S. (2013), "The safety journey: Using a safety maturity model for safety planning and assurance in the UK coal mining Industry", Minerals,

Vol. 3 No. 1, pp. 59-72.

Gangolells, M., Casals, M., Gasso, S., Forcada, N., Roca, X., and Fuertes, A. (2011), "Assessing concerns of interested parties when predicting the significance of environmental impact related to construction process of residential buildings", Building and Environment. Vol. 46 No. 5, pp.1023-1037.

Gasparik, J. (2009), "Integrated management system in construction company-effective tool of quality, environment and safety level improving", Organization, Technology and Management in Construction: An International Journal, Vol. 1 No. 1, pp 15-21.

Goggin, A., and Rankin, J.H. (2010), Health and Safety Maturity Model for New Brunswick Construction Industry, Master's thesis, University of New Brunswick.

Global Construction Perspectives and Oxford Economics (2015) 'Global Construction 2030', available at: http://www.globalconstruction2030.com/ (accessed 3 March 2017).

Griffith, A., and Bhutto, K. (2008), "Improving environmental performance through integrated management systems (IMS) in the UK", Management of Environmental Quality: An International Journal, Vol. 19 No. 5, pp.565-578.

Hadi-Vencheh, A., Hadi-Vencheh, A., and Niazi-Motlagh, M. (2005), "An improved voting analytic hierarchy process-data envelopment analysis methodology for supplier's selection", International Journal of Computer Integrated Manufacturing, Vol. 24 No. 3, pp. 189-197.

Hale, A.R., Guldenmund, F.W., van Loenhout, P.L.C.H., and Oh, J.I.H. (2010), "Evaluating safety management and culture interventions to improve safety: effective intervention strategies", Safety Science, Vol. 48 No. 8, pp. 1026-1035.

Hallowell, M. R., and Gambatese, J. A. (2010), "Qualitative research: application of the Delphi method to CEM research", Journal of Construction Engineering and Management, Vol. 136 No. 1, pp. 99-107.

Hallowell, M.R. and Hansen, D. (2016), "Measurement and improving designer hazard recognition skill: Critical competency to enable prevention through design", Safety Science, Vol. 82, pp. 254-263. 
Han, S., Saba, F., Lee, S., Mohamed, Y., and Peña-Mora, F. (2014), "Toward an understanding of the impact of production pressure on safety performance in construction operations", Accident Analysis and Prevention, Vol. 68, pp. 106-116.

Haas, E.J., and Yorio, P. (2016), "Exploring the state of health and safety management system performance measurement in mining organizations, Safety Science, Vol. 83, pp. 48-58.

Heras-Saizarbitoria I, Molina-Azorín J.F, and Dick, G.P. (2011), "ISO 14001 certification and financial performance: selection-effect versus treatment-effect", Journal of Cleaner Production, Vol. 19 No. 1, pp. 1-12.

HSE (2013), Managing for Health and Safety- HSG65, 3rd ed. Suffolk: HSE

HSE (2018), 'Annual Injury and Ill-Health Statistics on Work-Related Health and Safety in Great Britain', available at: https://www.acornsafety.co.uk/hse-health-safety-statisticsreleased-2018/ (assessed 23 March 2018)

HSE (2020) Historical picture statistics in Great Britain, 2020. HSE. Available from https://www.hse.gov.uk/statistics/history/historical-picture.pdf [Accessed 4 October 2021]

ILO (2021), ILO sectoral brief, available at: https://www.ilo.org/wcmsp5/groups/public/--ed_dialogue/---sector/documents/briefingnote/wcms_767303.pdf (assessed 23 September 2021).

ILO (2015), Options for G20 activities to promote safe and healthy workplaces for all, Report prepared for the G20 Employment Working Group Meeting, Istanbul, Turkey, 6-8 May 2015, available at: http://g20.org.tr/wp-content/uploads/2015/11/Options-for-G20-Activities-toPromote-Safe-and-Healthy-Workplaces-for-All.pdf (accessed 23 September 2021).

ILO (2012), 'Estimating the Economic Costs of Occupational Injuries and Illnesses in Developing Countries, Essential information for decision-makers'. ILO www.ilo.org/wcmsp5/groups/public/---ed_protect/---protrav/-safework/documents/publication/wcms_207690.pdf (assessed 26 June 2018).

International Organisation of Standardisation (ISO) (2015), Environmental Management Systems (ISO 14001) - Requirements with Guidance for Use. Final Draft. ISO, Geneva.

Jazayeri, E. and Dadi, G.B. (2017), "Construction safety management systems and methods of safety performance measurement: A review”, Journal of Safety Engineering, Vol. 6 No. 2 pp.15-28.

Kheni, N., Gibb, A.G.F., and Dainty, A.R.J. (2008) Health and safety management in developing countries: A study of construction SMEs in Ghana. Construction Management and Economics. 26(11), pp. 1159-1169.

Lai, D.N.C., Liu, M., and Ling, F.Y.Y. (2011), "A comparative study on adopting human resource practices for safety management on construction projects in the United States and Singapore", International Journal of Project Management, Vol. 29 No. 8, pp. 1018-1032. 
Legendre, P. (2005), "Species associations: The Kendall coefficient of concordance revisited", Journal of Agricultural, Biological Environmental Statistics, Vol. 10 No. 2, pp. 226-245

Linstone, H.A., and Turoff, M. (2011), "Delphi: A brief look backward and forward". Technological Forecasting and Social Change, Vol. 78 No. 9, pp.1712-1719.

Lopez-Arquillos, A., Rubio-Romero, J.C., and Martinez-Aires, M.D. (2015), "Prevention through design (PtD): The importance of the concept in engineering and architecture university courses", Safety Science, Vol. 73, pp. 8-14.

Liu, F.H.F. and Hai, H.L. (2005), "The voting analytic hierarchy process method for selecting supplier”, International Journal of Production Economics, Vol. 97 No. 3, pp.308-317.

Manu, P., Poghosyan, A., Mahamadu, A.M., Mahdjoubi, L., Gibb, A., Behm, M., and Akinade, O. (2019), "Design for occupational safety and health: Key attributes for organisational capability", Engineering Construction Architecture Management. pp 1-24

Mohammadfam, I., Kamalinia, M., Momeni, M., Golmohammadi, R., Hamidi, Y., and Soltanian, A. (2017), "Evaluation of the quality of occupational health and safety management systems based on key performance indicators in certified organisations", Safety and Health at Work, Vol. 8, pp. 156-161

Moher, D., Liberati, A., Tetzlaff, J., and Altman, D.G. (2009), "Preferred reporting items for systematic reviews and meta-analyses: The PRISMA statement", PLoS Medicine. 6 (7), pp.16.

Mubita, K., Milupi, I., Monde, P.N., Simooya, S.M. and Phiri, T.K. (2021), "Safety education and training: On site lessons for workers in selected construction sites of Lusaka District", International Journal of Humanities Social Sciences and Education, Vol. 8 No. 3, pp. 39-51.

Ogbeifun E, Mbohwa, C., and Pretorius J.C. (2017), "Achieving consensus devoidof complicity: adopting the Delphi technique". International Journal of Productivity and Performance Management. Vol. 66 No. 6, pp.766-779.

Okoye, P. and Okolie, K. (2014), "Exploratory study of the cost of health and safety performance of building contractors in South-East Nigeria"., British Journal of Environmental Science. Vol. 2 No. 1, pp. 21-33.

Oliveira, O.J. (2013) Guidelines for the integration of certifiable management systems in industrial companies. Journal of Cleaner Production. 58, pp.124-133.

Opoku, A. (2019), "Biodiversity and the built environment: Implications for the sustainable development goals", Resources, Conservation and Recycling, Vol. 141, No. 2, pp. 1-7.

OSHA (2016) 'Recommended Practices for Safety and Health Programs', available at: www.osha.gov/shpguidelines (assessed 10 February 2019).

Owolana, V.O., and Booth, C.A. (2016), "Stakeholder perceptions of the benefits and barriers of implementing Environmental Management Systems in the Nigerian Construction Industry", Journal of Environmental Engineering and Landscape Management. Vol. 24 No. 2, pp. 79-89. 
Paulk, M.C., Chrissis C., and Weber, M.B (1993), "Capability maturity model for software version 1.1”, IEEE Software, Vol. 10 No. 4, pp 18-27.

Poghosyan, A., Manu, P., Mahamadu, A-M., Akinade, O., Mahdjoubi, L., Gibb, A., and Behm, M. (2020), "A web-based design for occupational safety and health capability maturity indicator", Safety Science.

Randeree, K., Mahal, A., and Narwani, A. (2012), "A business continuity management maturity model for the UAE banking sector", Business Process Management Journal, Vol. 18 No. 3 pp. 472-492.

Rebelo, M., Santos, G., and Silva, R. (2015), "Integration of standardized management systems: A dilemma? Systems". Systems, Vol. 3 No. 2, pp.45-59.

Rowe, G., and Wright, G. (1999), "The Delphi technique as a forecasting tool: Issues and analysis", International Journal of Forecasting, Vol. 15, pp. 353-375.

Saaty, T.L (1980), The Analytical Hierarchy Process. New York: McGraw-Hill.

Schmidt, J. S., and Osebold, R. (2017), "Environmental management systems as a driver for sustainability: state of implementation, benefits and barriers in German construction companies”, Journal of Civil Engineering and Management, Vol. 23 No. 1, pp. 150-162.

Schmidt, R. (1997), "Managing Delphi Surveys Using Nonparametric Statistical Techniques", Decision Sciences, Vol. 28 No. 3, pp. 763-774

Šelih, J., (2007), "Environmental management systems and construction SMES: A case study for Slovenia", Journal of Civil Engineering and Management, Vol. 13 No. 3, pp. 217-226.

Skulmoski, G.A., Hartman, F.T., and Krahn, J. (2007), "The Delphi method for graduate research", Journal of Information Technology Education, Vol. 6, pp. 1-21.

Sharp J.V., Strutt, J.E., Busby, J.J., and Terry, E.E. (2002), "Measurement of organisational maturity in designing safe offshore installations", International Conference on Offshore Mechanics and Arctic Engineering, 21st International Conference on Offshore Mechanics and Arctic Engineering. 2, pp. 383-390.

Stemn, E. (2019), "Analysis of injuries in the Ghanaian mining industry and priority areas for research", Safety and Health at Work, Vol. 10 (2019), pp. 151-165.

Succar, B. (2009), "Building information modelling maturity matrix": In Underwood, J. and Isikdag, U. (Eds), Handbook of Research on Building Information Modelling and Construction Informatics: Concepts and Technologies, Information Science Reference, Hershey, PA, pp. 65103.

Suárez Sánchez, F.A., Carvajal Peláez, G.I., and Catalá Alís, J. (2017), “Occupational safety and health in construction: a review of applications and trends", Industrial Health, Vol. 55 No. 3, pp. 210-218. 
Strutt, J.E., Sharp, Terry. E., and Miles, R. (2006), "Capability maturity models for offshore organisational management”, Environment International, Vol. 32 No. 8, pp. 1094-1105.

Sui, Y., Ding, R., and Wang, H. (2018) An integrated management system for occupational health and safety and environment in an operating nuclear power plant in East China and its management information system. Journal of Cleaner Production. 183, pp. 261-271.

Tepaskoualos, F. and Chountalas, P. (2017), "Implementing an integrated health, safety and environmental Management system: The case of a construction company", International Journal for Quality Research, Vol. 11 No. 4, pp. 733-752.

Tompa, E., Mofidi, A., Heuvel, S. v.d., Bree, T.v., Michaelson, F., Jung, Y., Porsch, L. and Emmerik, M.v. (2021), "Economic burden of work injuries and diseases: a framework and application in five European Union countries”, BMC Public Health, Vol. 21 (2021), pp. 1-10.

Vasilca, I.-S., Nen, M., Chivu, O., Radu, V., Simion, C.-P., Marinescu, N. (2021), "The Management of Environmental Resources in the Construction Sector: An Empirical Model", Energies, Vol. 14 (2021), pp. 2489. https://doi.org/10.3390/en14092489

Vidal, L., Marle, F., and Bocquet, J. (2011) Expert systems with applications using a Delphi process and the Analytic Hierarchy Process (AHP) to evaluate the complexity of projects. Expert Systems with Applications. 38(5), pp. 5388-5405.

Wachter, J.K., and Yorio, P.L. (2014) A system of safety management practices and worker engagement for reducing and preventing accidents: An empirical and theoretical investigation. Accident Analysis and Prevention. 68, pp. 117-130.

Williams, J., Adinyira, E. and Fugar, F.D.K. (2020), “Assessment of health and safety culture maturity in the construction industry in developing economies: A case of Ghanaian construction industry", Journal of Engineering, Design and Technology, Vol. 18 No. 4, pp. $865-881$.

Yiu, N.S.N., Sze, N.N., and Chan, D.W.M. (2018), "Implementation of safety management systems in Hong Kong construction industry- A safety practitioner's perspective". Journal of Safety Research. Vol. 64, pp. 1-9.

Zaira, M.M., and Hadikusumo, B.H.W. (2017), "Structural equation model of integrated safety interventions practises affecting the safety behaviour of workplace of workers in the construction industry. Safety Science, "Vol. 98, pp.124-135

Zar, J.H. (1999), Biostatistical Analysis. 4th ed. Upper Saddle River, New Jersey: Prentice Hall.

Zeng, S.X., Tam, V.W.Y., and Tam, C.M. (2008), "Towards occupational health and safety systems in the construction industry of China", Safety Science, Vol.46, pp. 1155-1168.

Zutshi, A., and Creed, A. (2015), "An international review of environmental initiatives in the construction sector”, Journal of Cleaner Production, Vol. 98, pp. 92-106.

Zaira, M.M., and Hadikusumo, B.H.W. (2017), "Structural equation model of integrated safety 
intervention practices affecting the safety behaviour of workers in the construction industry", Safety Science. Vol. 98, pp. 124-135. 


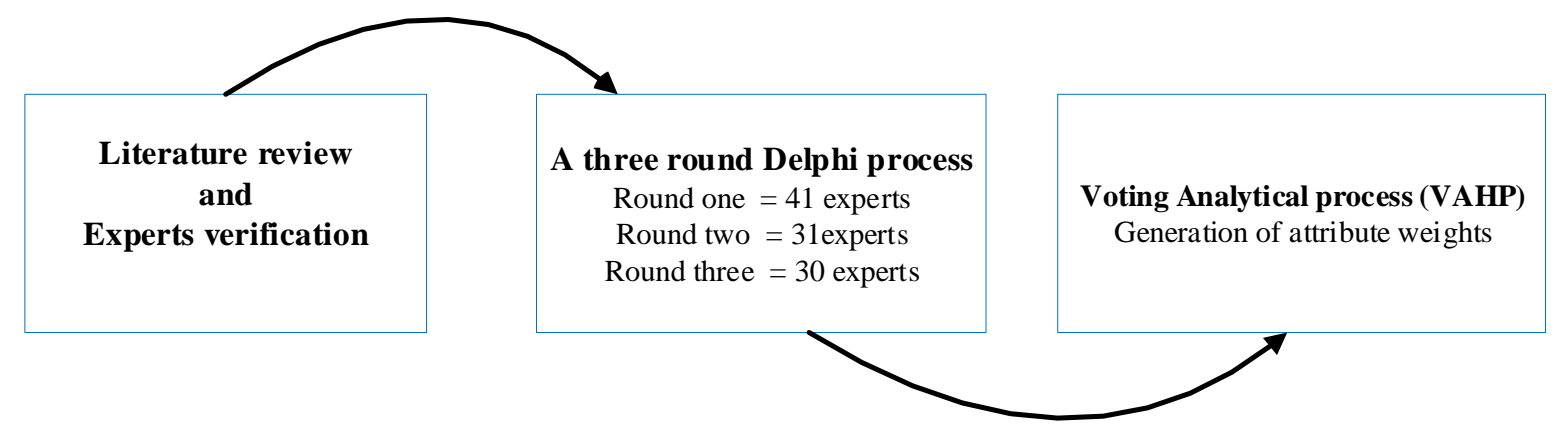

Figure.1: Overview of research process 


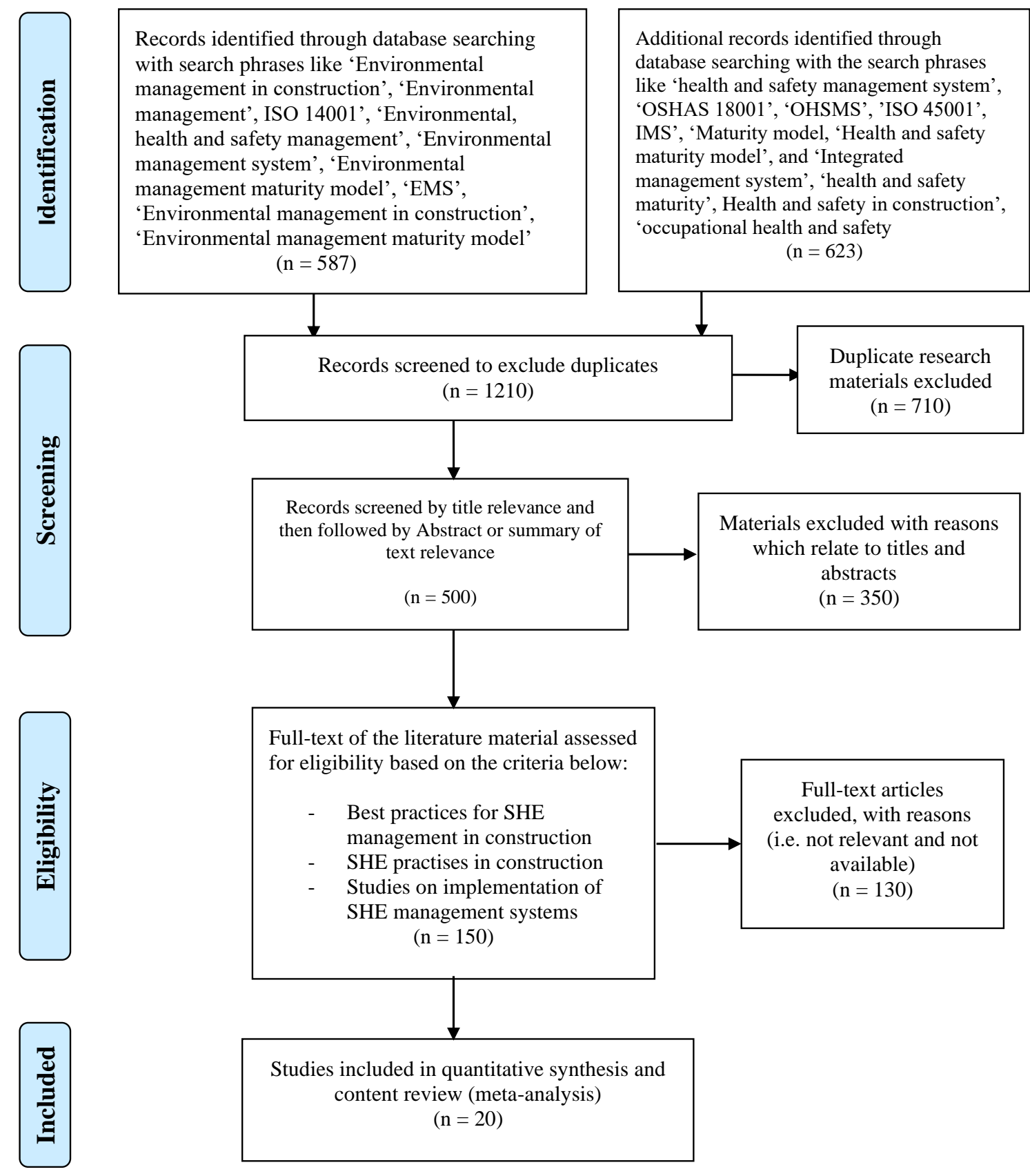

“ $\boldsymbol{n} "=$ number of documents

Figure 2: PRISMA Flowchart of the literature review process 


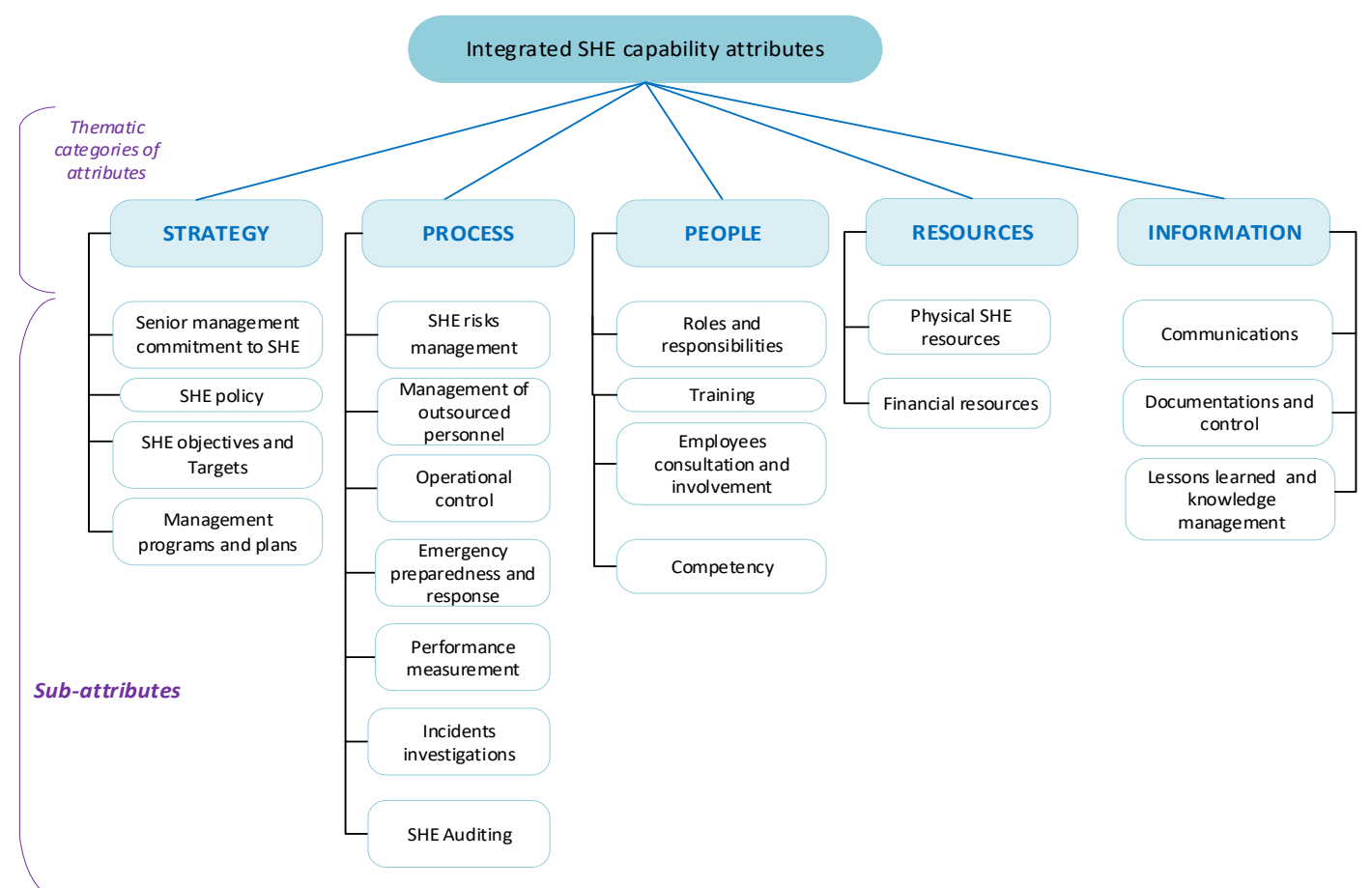

Figure 3: Integrated SHE management capability attributes hierarchy structure 
Table 1: SHE management capability attributes in construction from literature

\begin{tabular}{|c|c|c|}
\hline No. & $\begin{array}{l}\text { Aspect of Plan- } \\
\text { Do-Check-Act } \\
\text { (PDCA) }\end{array}$ & Attributes \\
\hline 1 & \multirow{9}{*}{$\frac{\overrightarrow{2}}{\mathrm{z}}$} & Senior management commitment \\
\hline 2 & & SHE implementation team \\
\hline 3 & & Baseline review \\
\hline 4 & & Hazards, environmental aspects and impacts identification \\
\hline 5 & & SHE risks assessment and identification of control measures \\
\hline 6 & & Legal and other requirements \\
\hline 7 & & SHE policy \\
\hline 8 & & SHE objectives and targets \\
\hline 9 & & SHE management programme \\
\hline 10 & \multirow{11}{*}{ 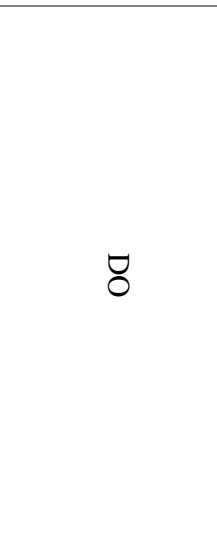 } & SHE roles and responsibilities \\
\hline 11 & & SHE resources \\
\hline 12 & & SHE training \\
\hline 13 & & SHE competence \\
\hline 14 & & Management of outsourced SHE services \\
\hline 15 & & SHE communication \\
\hline 16 & & Employee involvement in SHE \\
\hline 17 & & SHE documentation \\
\hline 18 & & Control of SHE documents \\
\hline 19 & & SHE operational control \\
\hline 20 & & SHE emergency preparedness and response \\
\hline 21 & \multirow{6}{*}{$\begin{array}{l}\stackrel{\Omega}{1} \\
\stackrel{7}{\pi}\end{array}$} & SHE performance monitoring and measurement \\
\hline 22 & & Evaluation of compliance \\
\hline 23 & & SHE incidents investigations \\
\hline 24 & & Non-conformance; corrective and preventive actions \\
\hline 25 & & SHE records control \\
\hline 26 & & SHE system auditing \\
\hline 27 & $\rightarrow$ & SHE lessons learned and knowledge management \\
\hline
\end{tabular}


Table 2: Characteristics of the applied Delphi process

\begin{tabular}{|c|c|c|}
\hline Characteristic & Requirements offered in literature & Applied characteristic \\
\hline Expertise & $\begin{array}{l}\text { - In-depth knowledge and experience with the } \\
\text { issues under investigation; capacity and } \\
\text { willingness to participate (Adler and Ziglio, } \\
\text { 1996; Hallowell and Gambatese, 2010) } \\
\text { - Years of professional experience in the } \\
\text { construction industry; Academic and } \\
\text { professional qualifications; sufficient time to } \\
\text { participate and effective communication skills } \\
\text { (Adler and Ziglio, 1996) }\end{array}$ & $\begin{array}{l}\text { Participant professional role must be } \\
\text { related SHE management in construction } \\
\text { - A minimum of } 5 \text { years of experience in } \\
\text { construction }\end{array}$ \\
\hline $\begin{array}{l}\text { Number of } \\
\text { experts }\end{array}$ & $\begin{array}{l}\text { - Optimal size between 7-30 } \\
\text { - Minimum of eight (8) (Hallowell and } \\
\text { Gambatese, 2010) } \\
\text { - Minimum of ten (10) Skulmoski et al., 2007) } \\
\text { - In CEM Delphi applications participants can } \\
\text { range from 3-90 members with most studies } \\
\text { using panels of } 15 \text { to } 35 \text { people (Ameyaw et } \\
\text { al., 2016). }\end{array}$ & $\begin{array}{l}\text { - } 41 \text { experts in Round } 1 \\
\text { - } 32 \text { experts in Round } 2 \\
\text { - } 30 \text { experts in Round } 3\end{array}$ \\
\hline $\begin{array}{l}\text { Number of } \\
\text { iterations }\end{array}$ & $\begin{array}{l}\text { - Two to six rounds (e.g. Dalkey et al., 1970; } \\
\text { Linstone and Turoff, 1975) } \\
\text { - Three (3) rounds (Hallowell and Gambatese, } \\
\text { 2010) with round one usually being } \\
\text { exploratory for identification of items or } \\
\text { elements }\end{array}$ & $\begin{array}{l}\text { Three rounds. A preliminary round } \\
\text { to identify factors (in this case the } \\
\text { integrated SHE capability attributes) was } \\
\text { not needed as attributes had already been } \\
\text { identified from literature which was } \\
\text { validated by experts. }\end{array}$ \\
\hline $\begin{array}{l}\text { Controlled } \\
\text { feedback }\end{array}$ & $\begin{array}{l}\text { - Measures of central tendency and level of } \\
\text { dispersion } \\
\begin{aligned} &- \text { Median (Hsu and Sanford, 2007, } \\
& \text { - } \text { Ameyaw et al., 2016) } \\
& \text { Mean (Ameyaw et al., 2016) }\end{aligned}\end{array}$ & $\begin{array}{l}\text { Median was used due to the use of ordinal } \\
\text { scale in the Delphi questionnaire }\end{array}$ \\
\hline $\begin{array}{l}\text { Measurement of } \\
\text { consensus (i.e. } \\
\text { level of } \\
\text { agreement) }\end{array}$ & $\begin{array}{l}\text { - Using non-parametric, measures of central } \\
\text { tendency, level of dispersion and parametric } \\
\text { statistical methods. } \\
\text { - } \quad \text { Kendall's coefficient of concordance } \\
\text { (W) (Ameyaw et al., 2016) } \\
\text { - Consistency Ratio (Ameyaw et al., } \\
\text { 2016) } \\
\text { - Standard Deviation (Ameyaw et al., } \\
\text { 2016) } \\
\text { - Absolute deviation (Hallowell and } \\
\text { Gambatese, 2010; Ameyaw et al., } \\
\text { 2016) }\end{array}$ & $\begin{array}{l}\text { - } \text { Kendall's was used due to the use of } \\
\text { ranked responses (i.e. ordinal data) } \\
\text { A non-parametric test -Wilcoxon signed } \\
\text { ranked test was used to ascertain the } \\
\text { saturation between Delphi rounds } \\
\text { (Linstone and Turoff, 2011). This test } \\
\text { ascertains the differences between two set } \\
\text { of scores from the same participants (Field, } \\
\text { 2013), thus, appropriate for investigating if } \\
\text { there are any significant changes in } \\
\text { participants scores from one round to } \\
\text { another. }\end{array}$ \\
\hline
\end{tabular}


Table 3: The coefficient $\mathrm{w}_{\mathrm{s}}$ according to the different attributes and sub attributes

\begin{tabular}{|c|c|c|c|}
\hline Thematic category & Number of attributes/sub & \multicolumn{2}{|c|}{ Coefficient of weights $\left(W_{s}\right)$} \\
\hline $\begin{array}{l}\text { All five categories (i.e. } \\
\text { strategy, process, people, } \\
\text { resources and information) }\end{array}$ & 5 & $\begin{array}{l}\mathrm{W}_{1} \\
\mathrm{w}_{2} \\
\mathrm{w}_{3} \\
w_{4} \\
w_{5}\end{array}$ & $\begin{array}{l}0.4380 \\
0.2180 \\
0.1460 \\
0.1095 \\
0.0876\end{array}$ \\
\hline Strategy & 4 & $\begin{array}{l}w_{1} \\
w_{2} \\
w_{3} \\
w_{4}\end{array}$ & $\begin{array}{l}0.4800 \\
0.2400 \\
0.1600 \\
0.1200\end{array}$ \\
\hline Process & 7 & $\begin{array}{l}w_{1} \\
w_{2} \\
w_{3} \\
w_{4} \\
w_{5} \\
w_{6} \\
w_{7}\end{array}$ & $\begin{array}{l}0.3857 \\
0.1928 \\
0.1286 \\
0.0964 \\
0.0771 \\
0.0643 \\
0.0551\end{array}$ \\
\hline People & 4 & $\begin{array}{l}w_{1} \\
w_{2} \\
w_{3} \\
w_{4}\end{array}$ & $\begin{array}{l}0.4800 \\
0.2400 \\
0.1600 \\
0.1200\end{array}$ \\
\hline Resources & 2 & $\begin{array}{l}w_{1} \\
w_{2}\end{array}$ & $\begin{array}{l}0.6667 \\
0.3333\end{array}$ \\
\hline Information & 3 & $\begin{array}{l}w_{1} \\
w_{2} \\
w_{3}\end{array}$ & $\begin{array}{l}0.5455 \\
0.2720 \\
0.1818\end{array}$ \\
\hline
\end{tabular}


Table 4: Results of the expert survey

Proposed SHE capability attributes

Number of expert participants (12)

Response received: $(9)=75 \%$ response rate

Agree $\%$ of agreement Disagree

\begin{tabular}{llll}
\hline Top management commitment & 9 & 100 & 0 \\
\hline SHE implementation team & 7 & 78 & 2 \\
\hline SHE baselines review & 6 & 67 & 3 \\
\hline SHE policy & 8 & 89 & 1 \\
\hline SHE hazards, environmental aspects and impacts identification & 8 & 89 & 1 \\
\hline SHE risks assessments and management & 7 & 78 & 2 \\
\hline SHE legal and other requirements & 7 & 78 & 2 \\
\hline SHE objectives and targets & 6 & 67 & 3 \\
\hline SHE management programme(s)/action plan (s) & 8 & 89 & 1 \\
\hline SHE structures and responsibility & 8 & 89 & 1 \\
\hline SHE resources & 8 & 89 & 1 \\
\hline SHE training & 7 & 78 & 2 \\
\hline Competency of workforce & 7 & 78 & 2 \\
\hline SHE supervision & 7 & 78 & 2 \\
\hline SHE communications & 8 & 89 & 1 \\
\hline SHE legal and other requirements & 5 & 56 & 4 \\
\hline SHE documentation & 8 & 89 & 1 \\
\hline SHE documents control & 7 & 78 & 2 \\
\hline SHE operational control & 7 & 78 & 2 \\
\hline SHE emergency preparedness and response & 8 & 89 & 1 \\
\hline Monitoring and measurement & 9 & 100 & 0 \\
\hline Evaluation of legal compliance & 7 & 78 & 2 \\
\hline SHE incidents investigation & 8 & 89 & 1 \\
\hline Non-conformance, correction/prevention action & 8 & 89 & 1 \\
\hline Records control & 6 & 67 & 3 \\
\hline SHE auditing & 7 & 78 & 2 \\
\hline SHE management review & 8 & 89 & 1 \\
\hline Learning lessons & 8 & & 1 \\
\hline & & 89 & \\
\hline
\end{tabular}


Table 5: SHE management attributes

\begin{tabular}{l|l}
\hline Thematic Category & Attributes \\
\hline $\begin{array}{l}\text { Strategy (i.e. the organisation's vision and top } \\
\text { management commitment to SHE management) }\end{array}$ & $\begin{array}{l}\text { Senior management commitment to safety, health and } \\
\text { environment (SHE) management }\end{array}$ \\
\cline { 2 - 2 } & An
\end{tabular}

An integrated SHE policy that serves as the foundation for a company's SHE development and implementation

SHE objectives and targets for a company, in line with SHE policy

SHE management programme i.e. company's action plans for achieving SHE objectives and targets

Processes (i.e. the organisation's procedures, processes and systems for SHE management)

SHE risks management i.e. systems, processes and procedures for SHE hazards identification, risks assessment and identification risks control strategies Management of outsourced services i.e. processes and mechanisms for assessing the competence of outsourced personnel, subcontractors and suppliers with regards to management of SHE

SHE operational control i.e. processes, procedures and measures for controlling SHE risks, to ensure SHE regulatory compliance in operational functions and to achieve the overall SHE objectives

SHE emergency preparedness and responses i.e. emergency procedures and measures to minimise the impact of uncontrolled events and unexpected incidents.

SHE performance monitoring and measurement i.e. systems, processes and procedures to monitor and measure SHE performance to ensure compliance with SHE regulations

SHE incidents investigation i.e. processes and procedures for investigating the causes of SHE incidents

SHE system auditing i.e. processes and procedures to conduct SHE audits to assess compliance and SHE management system effectiveness

People (i.e. organisation's human capital, their roles, responsibilities, and involvement in SHE SHE roles and responsibilities i.e. availability of dedicated SHE roles and responsibilities within management) organisational hierarchy

SHE Training i.e. provision of suitable SHE training for personnel

Employee involvement and consultation at all levels in SHE management and operations

SHE competence i.e. the skills, knowledge and experience of personnel to undertake responsibilities and perform SHE activities

Resources (i.e. organisation's physical and financial Physical SHE resources i.e. provision of physical resources required for SHE management) resources for SHE implementation Financial resources for SHE i.e. Provision of financial resources for SHE implementation

Communications i.e. communication of relevant SHE information and requirements to personnel and other relevant stakeholders

SHE documentation and control i.e. provision and maintenance of adequate SHE documentation and

Information (i.e. SHE related documents, data, records

lessons, records and their communication across an organisation) SHE lessons and knowledge management i.e. capturing lessons learned and knowledge acquired from historical incidents and management of SHE

Communications i.e. Communication of relevant SHE information and requirements to personnel and other relevant stakeholders 


\begin{tabular}{|c|c|c|c|c|c|c|c|c|c|c|c|c|}
\hline \multirow[t]{2}{*}{ Thematic category /attributes } & \multicolumn{4}{|c|}{ Round $1(\mathrm{~N}=41)$} & \multicolumn{4}{|c|}{ Round $2(\mathrm{~N}=31)$} & \multicolumn{4}{|c|}{ Round $3(\mathrm{~N}=30)$} \\
\hline & Median & $\begin{array}{c}\text { Mean } \\
\text { rank }\end{array}$ & $\begin{array}{l}\text { Kendall's } \\
\text { W }\end{array}$ & $\begin{array}{l}\text { Significant } \\
\text { value }\end{array}$ & Median & $\begin{array}{l}\text { Mean } \\
\text { rank }\end{array}$ & $\begin{array}{l}\text { Kendall's } \\
\text { W }\end{array}$ & $\begin{array}{l}\text { Significant } \\
\text { value. }\end{array}$ & Median & $\begin{array}{c}\text { Mean } \\
\text { rank }\end{array}$ & $\begin{array}{l}\text { Kendall's } \\
\text { W }\end{array}$ & $\begin{array}{l}\text { Significant } \\
\text { value }\end{array}$ \\
\hline Thematic category of attributes & & & \multirow{6}{*}{0.425} & \multirow{6}{*}{0.000} & & & \multirow{6}{*}{0.481} & \multirow{6}{*}{0.000} & & & \multirow{6}{*}{ N/A } & \\
\hline Strategy & 1 & 1.71 & & & 1 & 1.61 & & & & & & \\
\hline Processes & 2 & 2.73 & & & 2 & 2.94 & & & & & & \\
\hline People & 2 & 2.76 & & & 2 & 2.65 & & & & & & \\
\hline Resources & 3 & 3.49 & & & 3 & 3.44 & & & & & & \\
\hline Information & 4 & 4.32 & & & 5 & 4.37 & & & & & & \\
\hline \multicolumn{7}{|l|}{ Strategy attributes } & \multirow{5}{*}{0.610} & \multirow{5}{*}{0.000} & & & \multirow{5}{*}{ N/A } & \\
\hline Senior Management Commitment & 1 & 1.91 & \multirow{4}{*}{0.388} & \multirow{4}{*}{0.000} & 1 & 1.66 & & & & & & \\
\hline SHE Policy & 1 & 1.91 & & & 1 & 1.79 & & & & & & \\
\hline SHE Objectives and Targets & 3 & 2.84 & & & 3 & 3.11 & & & & & & \\
\hline SHE Management Programme & 3 & 3.33 & & & 3 & 3.44 & & & & & & \\
\hline Processes & & & \multirow{8}{*}{0.258} & \multirow{8}{*}{0.000} & & & \multirow{8}{*}{0.401} & \multirow{8}{*}{0.000} & & & \multirow{8}{*}{ N/A } & \\
\hline SHE Risk Management & 1 & 2.32 & & & 1 & 1.90 & & & & & & \\
\hline Management of Outsourced Services & 3 & 4.67 & & & 4 & 4.53 & & & & & & \\
\hline SHE Operational Control & 2 & 2.98 & & & 2 & 2.71 & & & & & & \\
\hline SHE Emergency Preparedness and Responses & 4 & 4.38 & & & 5 & 4.84 & & & & & & \\
\hline SHE Performance Monitoring and Measurement & 3 & 3.98 & & & 3 & 3.66 & & & & & & \\
\hline SHE Incidents Investigation & 5 & 4.96 & & & 5 & 5.35 & & & & & & \\
\hline SHE System Auditing & 4 & 4.72 & & & 5 & 5.00 & & & & & & \\
\hline People attributes & & & \multirow{5}{*}{0.067} & \multirow{5}{*}{0.041} & & & \multirow{5}{*}{0.402} & \multirow{5}{*}{0.000} & & & \multirow{5}{*}{ N/A } & \\
\hline SHE roles and responsibilities & 2 & 2.27 & & & 2 & 2.60 & & & & & & \\
\hline SHE Training & 2 & 2.68 & & & 3 & 2.98 & & & & & & \\
\hline Employee Involvement in SHE & 2 & 2.82 & & & 3 & 3.03 & & & & & & \\
\hline SHE Competence & 2 & 2.23 & & & 1 & 1.39 & & & & & & \\
\hline Resources attributes & & & & \multirow{3}{*}{0.695} & & & & & & & & \\
\hline Physical SHE Resources & 1 & 1.52 & 0.004 & & 1 & 1.53 & 0.008 & 0.617 & 1 & 1.42 & 0.064 & 0.166 \\
\hline Financial Resources for SHE & 1 & 1.48 & & & 1 & 1.47 & & & 1 & 1.58 & & \\
\hline Information attributes & & & & & & & & & & & & \\
\hline Communications & 1 & 1.55 & & & 1 & 1.26 & & & & & & \\
\hline SHE documentation and control & 2 & 2.04 & 0.231 & 0.000 & 2 & 2.23 & 0.549 & 0.000 & & & N/A & \\
\hline SHE Lessons and Knowledge Management & 2 & 2.41 & & & 2 & 2.52 & & & & & & \\
\hline
\end{tabular}


Table 7: Wilcoxon signed rank test

\begin{tabular}{|c|c|c|c|c|c|c|}
\hline Comparison & & $\mathrm{N}$ & $\begin{array}{c}\text { Mean } \\
\text { rank }\end{array}$ & $\begin{array}{c}\text { Sum of } \\
\text { ranks }\end{array}$ & $\begin{array}{l}\text { Wilcoxon } \\
\text { signed ranks } \\
\text { (Z) }\end{array}$ & $\begin{array}{l}\text { Sig. (2- } \\
\text { tailed) }\end{array}$ \\
\hline \multirow{4}{*}{$\begin{array}{l}\text { Phy.Res (round 3) - Phy.Res } \\
\text { (round 2) }\end{array}$} & Negative Ranks & $5^{\mathrm{a}}$ & 3.500 & 17.500 & \multirow[t]{4}{*}{$-1.633^{b}$} & \multirow[t]{4}{*}{0.102} \\
\hline & Positive Ranks & $1^{\mathrm{b}}$ & 3.500 & 3.500 & & \\
\hline & Ties & $24^{\mathrm{c}}$ & & & & \\
\hline & Total & 30 & & & & \\
\hline \multirow[t]{4}{*}{ FIN3 - FIN2 } & Negative Ranks & $1^{\mathrm{a}}$ & 2.500 & 2.500 & \multirow[t]{4}{*}{$-1.000^{\mathrm{b}}$} & \multirow[t]{4}{*}{0.317} \\
\hline & Positive Ranks & $3^{\mathrm{b}}$ & 2.500 & 7.500 & & \\
\hline & Ties & $26^{\mathrm{c}}$ & & & & \\
\hline & Total & 30 & & & & \\
\hline
\end{tabular}

\section{Notes:}

Phy.res $=$ Physical resources. FIN = Financial resources.

$\mathrm{a}=$ the count of the round 3 ranks that are less than the round 2 ranks

$\mathrm{b}=$ the count of the round 3 ranks that are greater than the round 2 ranks

$\mathrm{c}=$ the count of the round 3 ranks that are equal to the round 2 ranks 
Table 8: Delphi priority votes applied in VAHP

\begin{tabular}{|c|c|c|c|c|c|c|c|c|}
\hline \multirow[t]{2}{*}{ Thematic category of attributes } & \multicolumn{5}{|c|}{ Priority votes at round 2} & & & \multirow[t]{2}{*}{ Total } \\
\hline & $1 \mathrm{st}$ & 2nd & $3 \mathrm{rd}$ & 4 th & \multicolumn{3}{|l|}{5 th } & \\
\hline Strategy & 28 & 1 & 0 & 1 & \multicolumn{3}{|l|}{1} & 31 \\
\hline Process & 7 & 10 & 8 & 6 & \multicolumn{3}{|l|}{0} & 31 \\
\hline People & 9 & 12 & 8 & 0 & \multicolumn{3}{|l|}{2} & 31 \\
\hline Resources & 6 & 4 & 8 & 11 & \multicolumn{3}{|l|}{2} & 31 \\
\hline Information & 4 & 1 & 2 & 5 & \multicolumn{3}{|l|}{19} & 31 \\
\hline \multirow[t]{2}{*}{ Strategy attributes } & \multicolumn{7}{|c|}{ Priority votes at round 2} & \multirow[t]{2}{*}{ 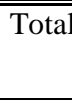 } \\
\hline & $1 \mathrm{st}$ & 2nd & 3rd & \multicolumn{4}{|l|}{ 4th } & \\
\hline Senior management commitment & 25 & 4 & 1 & \multicolumn{4}{|l|}{1} & 31 \\
\hline SHE Policy & 22 & 8 & 1 & \multicolumn{4}{|l|}{0} & 31 \\
\hline SHE objectives and Targets & 3 & 4 & 20 & \multicolumn{4}{|l|}{4} & 31 \\
\hline Management programs and plans & 3 & 4 & 11 & \multicolumn{4}{|l|}{13} & 31 \\
\hline \multirow[t]{2}{*}{ Process attributes } & \multicolumn{7}{|c|}{ Priority votes at round 2} & \multirow[t]{2}{*}{ Total } \\
\hline & $1 \mathrm{st}$ & 2nd & $3 \mathrm{rd}$ & 4 th & 5 th & 6 th & 7 th & \\
\hline SHE Risks Management & 25 & 2 & 0 & 2 & 2 & 0 & 0 & 31 \\
\hline Management of Outsource personnel & 3 & 3 & 9 & 5 & 3 & 5 & 3 & 31 \\
\hline Operational control & 7 & 15 & 6 & 3 & 0 & 0 & 0 & 31 \\
\hline Emergency preparedness and response & 4 & 3 & 2 & 4 & 11 & 6 & 1 & 31 \\
\hline Performance measurement & 4 & 7 & 12 & 5 & 1 & 2 & 0 & 31 \\
\hline Incidents investigations & 3 & 2 & 4 & 3 & 4 & 7 & 8 & 31 \\
\hline SHE Auditing & 4 & 2 & 4 & 3 & 7 & 7 & 4 & 31 \\
\hline \multirow[t]{2}{*}{ People } & \multicolumn{5}{|c|}{ Priority votes at round 2} & & & \multirow[t]{2}{*}{ Total } \\
\hline & $1 \mathrm{st}$ & 2nd & $3 \mathrm{rd}$ & \multicolumn{4}{|l|}{ 4th } & \\
\hline Roles and Responsibilities & 9 & 9 & 8 & \multicolumn{4}{|l|}{5} & 31 \\
\hline Training & 4 & 5 & 18 & \multicolumn{4}{|l|}{4} & 31 \\
\hline Employees consultation and involvement & 7 & 4 & 9 & 11 & & & & 31 \\
\hline Competency & 27 & 4 & 0 & 0 & & & & 31 \\
\hline Resources & & tiority & otes a & ound & & & & Total \\
\hline & $1 \mathrm{st}$ & 2nd & & & & & & \\
\hline Physical SHE resources & 26 & 4 & & & & & & 30 \\
\hline Financial resources & 21 & 9 & & & & & & 30 \\
\hline Information & & ciority & otes a & ound & & & & Total \\
\hline & $1 \mathrm{st}$ & 2nd & 3rd & & & & & \\
\hline Communications & 28 & 3 & 0 & & & & & 31 \\
\hline Documentation and control & 9 & 16 & 6 & & & & & 31 \\
\hline Lessons and knowledge management & 4 & 16 & 11 & & & & & 31 \\
\hline
\end{tabular}


Table 9: VAHP Results of thematic category of attributes

\begin{tabular}{|c|c|c|c|}
\hline Thematic category /attributes & Weight & Normalised weight & Rank \\
\hline \multicolumn{4}{|l|}{ Thematic category of attributes } \\
\hline Strategy & 12.678 & 0.332 & 1 \\
\hline Process & 7.080 & 0.185 & 3 \\
\hline People & 7.912 & 0.207 & 2 \\
\hline Resources & 6.051 & 0.158 & 4 \\
\hline Information & 4.475 & 0.117 & 5 \\
\hline \multicolumn{4}{|l|}{ Strategy attributes } \\
\hline Senior management commitment to SHE & 13.240 & 0.351 & 1 \\
\hline SHE Policy & 12.640 & 0.336 & 2 \\
\hline SHE objectives and Targets & 6.080 & 0.161 & 3 \\
\hline Management programs and plans & 5.720 & 0.152 & 4 \\
\hline \multicolumn{4}{|l|}{ Process attributes } \\
\hline SHE Risks Management & 10.375 & 0.275 & 1 \\
\hline Management of outsource personnel & 4.093 & 0.108 & 4 \\
\hline Operational control & 6.653 & 0.176 & 2 \\
\hline Emergency preparedness and response & 4.053 & 0.107 & 5 \\
\hline Performance measurement & 5.123 & 0.136 & 3 \\
\hline Incidents investigations & 3.546 & 0.094 & 7 \\
\hline SHE auditing & 3.942 & 0.104 & 6 \\
\hline \multicolumn{4}{|l|}{ People } \\
\hline Roles and responsibilities & 8.360 & 0.233 & 2 \\
\hline Training & 6.480 & 0.181 & 4 \\
\hline Employees consultation and involvement & 7.080 & 0.196 & 3 \\
\hline Competency & 13.920 & 0.388 & 1 \\
\hline \multicolumn{4}{|l|}{ Resources } \\
\hline Physical SHE resources & 18.667 & 0.523 & 1 \\
\hline Financial resources & 17.000 & 0.477 & 2 \\
\hline \multicolumn{4}{|l|}{ Information } \\
\hline Communications & 16.091 & 0.460 & 1 \\
\hline Documentation and control & 10.364 & 0.296 & 2 \\
\hline Lessons learned and knowledge management & 8.546 & 0.244 & 3 \\
\hline
\end{tabular}


Table 10: VAHP results of global ranking of attributes

\begin{tabular}{|l|c|c|}
\hline Capability attributes & Global weights & Global ranks \\
\hline \hline Senior management commitment to SHE & 0.1166 & 2 \\
\hline SHE Policy & 0.1113 & 3 \\
\hline Physical SHE resources & 0.0829 & 4 \\
\hline Competency & 0.0805 & 5 \\
\hline Financial resources & 0.0755 & 6 \\
\hline SHE objectives and targets & 0.0540 & 7 \\
\hline Communications & 0.0539 & 8 \\
\hline SHE risks management & 0.0511 & 9 \\
\hline Management programs and plans & 0.0509 & 10 \\
\hline Roles and responsibilities & 0.0483 & 12 \\
\hline Documentation and control & 0.0471 & 13 \\
\hline Employees consultation and involvement & 0.0409 & 14 \\
\hline Training & 0.0375 & 15 \\
\hline Operational control & 0.0347 & 16 \\
\hline Lessons and knowledge management & 0.0326 & 17 \\
\hline Performance measurement & 0.0286 & 18 \\
\hline Management of outsource personnel & 0.0251 & 20 \\
\hline Emergency preparedness and response & 0.0201 & 0.0199 \\
\hline SHE auditing & 0.0193 & 19 \\
\hline Incidents investigations & & 18 \\
\hline
\end{tabular}

